\title{
Fate of sulphate removed during the treatment of circumneutral mine water and acid mine drainage with coal fly ash: Modelling and experimental approach
}

Godfrey Madzivire ${ }^{a, \Uparrow}$, Wilson M. Gitari ${ }^{b}$, V.R. Kumar Vadapalli ${ }^{c}$, Tunde V. Ojumu ${ }^{d}$, Leslie F. Petrik ${ }^{\mathrm{a}}$

a Environmental \& Nano Sciences Research Group, Chemistry Department, University of the Western Cape, Modderdam Road, Private Bag X17, Bellville, 7535 Cape Town, South Africa

b Department of Ecology and Resources Management, School of Environmental Studies, University of Venda, Private Bag X5050, Thohoyandou 0950, South Africa

c Natural Resources and Environment Department, Council for Scientific and Industrial Research, P.O. Box 395, Pretoria, South Africa

d Department of Chemical Engineering, Faculty of Engineering, Cape Peninsula University of Technology, Cape Town Campus, P.O. Box 652, Cape Town 8000, South Africa

Corresponding author. Tel.: +27 82593 1436; fax: +27 219593878 .

E-mail address: gmadzivire@uwc.ac.za (G. Madzivire)

\section{Abstract}

The treatment of acid mine drainage (AMD) and circumneutral mine water (CMW) with South African coal fly ash (FA) provides a low cost and alternative technique for treating mine wastes waters. The sulphate concentration in AMD can be reduced significantly when AMD was treated with the FA to $\mathrm{pH}$ 9. On the other hand an insignificant amount of sulphate was removed when CMW (containing a very low concentration of $\mathrm{Fe}$ and $\mathrm{Al}$ ) was treated using $\mathrm{FA}$ to $\mathrm{pH} 9$. The levels of $\mathrm{Fe}$ and $\mathrm{Al}$, and the final solution $\mathrm{pH}$ in the AMD-fly ash mixture played a significant role on the level of sulphate removal in contrast to CMW-fly ash mixtures. In this study, a modelling approach using PHREEQC geochemical modelling software was combined with AMD-fly ash and/or CMW-fly ash neutralization experiments in order to predict the mineral phases involved in sulphate removal. The effects of solution $\mathrm{pH}$ and $\mathrm{Fe}$ and $\mathrm{Al}$ concentration in mine water on sulphate were also investigated. The results obtained showed that sulphate, $\mathrm{Fe}, \mathrm{Al}, \mathrm{Mg}$ and $\mathrm{Mn}$ removal from AMD and/or CMW with fly ash is a function of solution $\mathrm{pH}$. The presence of $\mathrm{Fe}$ and $\mathrm{Al}$ in AMD exhibited buffering characteristic leading to more lime leaching from FA into mine water, hence increasing the concentration of $\mathrm{Ca}^{2+}$. This resulted in increased removal of sulphate as $\mathrm{CaSO}_{4}-2 \mathrm{H}_{2} \mathrm{O}$. In addition the sulphate removal was enhanced through the precipitation as $\mathrm{Fe}$ and $\mathrm{Al}$ oxy-hydroxysulphates (as shown by geochemical modelling) in AMD-fly ash system. The low concentration of Fe and $\mathrm{Al}$ in $\mathrm{CMW}$ resulted in sulphate removal depending mainly on $\mathrm{CaSO}_{4}-2 \mathrm{H}_{2} \mathrm{O}$. The 
results of this study would have implications on the design of treatment methods relevant for different mine waters.

Keywords: Fly ash, Circumneutral mine water, Acid mine drainage, PHREEQC geochemical modelling and sulphates

\section{Introduction}

Freshwater resources around the world are under stress due to increasing population coupled with pollution of ground and surface water as a result of industrial and domestic activities. Typical pollutants of South Africa's water resources include industrial effluents, domestic and commercial sewage, mine waters, agricultural run-off and litter (Davies et al., 1993). Mine water is a source of heavy metal and sulphate contamination of surface and ground water. The microbial oxidation of sulphide minerals, such as pyrite, in the presence of oxygen and water has been shown to be responsible for the presence of the sulphate ion in mine water as shown in Eq. (1) (Younger et al., 2002).

$$
2 \mathrm{FeS}_{2}+\frac{15}{2} \mathrm{O}_{2}+\mathrm{H}_{2} \mathrm{O} \stackrel{\text { matprifis }}{\longrightarrow} 2 \mathrm{Fe}^{3+}+2 \mathrm{H}^{+}+4 \mathrm{SO}^{2}
$$

The resulting acid generated in this reaction causes chemical weathering of the surrounding rocks resulting in leaching of heavy metals into the water. The characteristics of mine water depend on the mineralogy of the surrounding rock (Lottermoser, 2007; Younger et al., 2002; Blowes and Ptacek, 1994). Circumneutral mine water is generated when the surrounding rock typically contains equal stoichiometric proportions of dolomite, limestone and pyrite. Therefore, CMW is generated when the acidity formed as a result of pyrite oxidation is neutralized in situ by dolomite dis- solution. This will cause $\mathrm{Al}$ and $\mathrm{Fe}$ to precipitate as hydroxides $(\mathrm{pH}>3.5)$ while the weathering of dolomite causes the mine water to contain elevated concentrations of Ca and Mg (Eq. (2)). Some of the sulphate concentrations are removed from the mine water due to precipitation as gypsum.

$$
\begin{aligned}
& \mathrm{FeS}_{2}+\mathrm{CaMg}\left(\mathrm{CO}_{3}\right)_{2}+\frac{15}{4} \mathrm{O}_{2}+\frac{3}{2} \mathrm{H}_{2} \mathrm{O} \\
& \rightarrow \mathrm{Fe}(\mathrm{OH})_{3}+\mathrm{Ca}^{2+}+\mathrm{Mg}^{2+}+2 \mathrm{SO}_{4}^{2}+2 \mathrm{CO}_{2}
\end{aligned}
$$

On the other hand, acid mine drainage (AMD) is generated (Eq. (1)) when the surrounding rock contains higher proportions of pyrite than dolomite. Although sometimes the mine water contains significant amounts of $\mathrm{Ca}$ and $\mathrm{Mg}$ due to dolomite dissolution, the alkalinity produced during weathering of dolomite is not sufficient to neutralize the acidity generated by pyrite oxidation.

Several methods have been used in the treatment of polluted mine water; these include biological treatment, chemical treatment, ion exchange and membrane 
methods (Madzivire, 2010). Biological treatment using sulphate reducing bacteria (SRB) and chemical treatment using lime and limestone are usually employed for heavily contaminated mine water. Ion exchange and membrane methods are too expensive for the treatment of heavily contaminated mine water and pretreatment is generally required to avoid fouling of membranes and resins (Adriano et al., 1980; Bosman, 1983; Conlon, 1990; Johnson and Hallberg, 2005; Maree et al., 1989; Hlabela et al., 2007; Hammack et al., 2006).

Due to the high costs associated with chemical treatment technologies and long residence time requirement for biological treatment, there has been a concerted effort towards developing a cost effective alternative technology for treatment of mine water (Madzivire et al., 2010). The treatment of mine water using coal fly ash (FA) has proved to be promising (Petrik et al., 2003; Gitari et al., 2006, 2008; Madzivire et al., 2010). Fly ash is an abundant waste material from coal power stations in South Africa. Most coal combustion power stations in South Africa are built near the coal mines to reduce the transport costs. The leachate from FA is known to be highly alkaline and the treatment of AMD with FA has been investigated extensively and it has been shown that the water produced in the treatment process is free from heavy metals such as $\mathrm{Fe}, \mathrm{Al}, \mathrm{Mn}$, and that the sulphate concentration is reduced by $80 \%$ to the saturation level of gypsum of approximately $1500 \mathrm{ppm}$ (Gitari et al., 2006, 2008; Petrik et al., 2003; Vadapalli et al., 2008).

Recently, it was shown that treatment of CMW rich in $\mathrm{Mg}$ and $\mathrm{Ca}$ to $\mathrm{pH} 9$ with FA did not result in a significant sulphate removal (Madzivire et al., 2010). However, the authors showed that by raising the solution $\mathrm{pH}$ to 12 followed by seeding with gypsum crystals and addition of amorphous $\mathrm{Al}(\mathrm{OH}) 3$, the sulphate level can be reduced to an acceptable limit. The objective of this follow up study is to provide an understanding of the mechanism of removal by the use PHREEQC geochemical modelling, which was used to investigate the effect of $\mathrm{pH}$ and to evaluate the effect of $\mathrm{Fe}$ and $\mathrm{Al}$ concentration on sulphate removal from CMW when reacted with FA. The $\mathrm{Al}$ and Fe were added by mixing AMD with CMW. This study also provides an insight into the mineral phases responsible for removal of sulphates, $\mathrm{Fe}, \mathrm{Al}$ and $\mathrm{Mn}$ from mine water when treated with $\mathrm{FA}$.

\section{Materials and method}

The mine waters, CMW and AMD were collected from storage dams of two different coal mines in Mpumalanga, South Africa. The mine water was filtered using a hand pump through a $0.45 \mathrm{~lm}$ nucleopore membrane and cation samples were acidified with concentrated $\mathrm{HNO}_{3}$ to $\mathrm{pH}<2$. The samples $(100 \mathrm{ml}$ ) were sealed in plastic containers and kept at $4{ }^{\circ} \mathrm{C}$ until analysis. Cation analysis was performed using an inductively-coupled plasma-atomic emission spectrometry (ICP-AES) and inductively-coupled plasma-mass spectrometry (ICP-MS). The ICP-AES was used for concentration greater than $1 \mathrm{ppm}$ and ICP-MS was used for con centration less than $1 \mathrm{ppm}$. Anion analysis was performed using ion chromatography (IC). To confirm the quality assurance, analysis of the certified reference material was performed using ICP-AES, ICP-MS and IC before the analysis of the samples. 
Fly ash was collected from a nearby pulverized coal combustion power station in Mpumalanga. The FA was collected directly from the precipitators and kept in sealed plastic bags devoid of air to avoid carbonation of free lime to calcite. The mineral composition of FA was elucidated using qualitative or quantitative X-ray diffraction spectroscopy (XRD) and the morphology of FA was analyzed by scanning electron microscopy (SEM). The FA was analyzed for chemical composition using Xray fluorescence spectroscopy (XRF).

\subsection{Effect of final $p H$}

Experiments were carried out to investigate the effect of the final $\mathrm{pH}$ on sulphate, $\mathrm{Mg}$ and $\mathrm{Mn}$ removal by collecting water samples at different $\mathrm{pH}$ levels. Circumneutral mine water $(500 \mathrm{ml})$ of $\mathrm{pH} 6.5$ was mixed with FA (250 g) and stirred using an overhead stirrer. Aliquot samples were collected at $\mathrm{pH} 9.88,10.21$, 11.77 and 12.34. The samples were filtered through a $0.45 \mathrm{~lm}$ nucleopore filter membrane and analyzed using IC and ICP-AES and ICP-MS. The ICP-AES and ICP-MS samples were acidified to $\mathrm{pH}<3$ using concentrated $\mathrm{HNO}_{3}$ to stabilize the cations. All the samples were stored at $4{ }^{\circ} \mathrm{C}$ before analysis. The solid residues produced at $\mathrm{pH} 9.88,10.21,11.77$ and 12.34 were also analyzed using qualitative XRD and XRF to investigate the changes in mineralogical and chemical composition of the FA.

The $\mathrm{pH}$ and electrical conductivity (EC) were measured using a Hanna Hl 991301 portable $\mathrm{pH} / \mathrm{EC} / \mathrm{TDS} /$ temperature $\mathrm{pH}$ meter after every $5 \mathrm{~min}$. The $\mathrm{pH}$ and EC were the parameters used to measure the progress of experiment. Before using the $\mathrm{pH}$ meter, it was calibrated using fresh buffers of $\mathrm{pH} 4$ and 7 or 10 depending on the $\mathrm{pH}$ range to be measured. Electrical conductivity of the water was calibrated using an EC calibration solution with a conductivity of $12.88 \mathrm{~ms} / \mathrm{cm}$.

\subsection{Effect of $\mathrm{Fe}$ and $\mathrm{Al}$ on sulphate removal}

Circumneutral mine water and AMD were mixed in the following ratios; 1:0 1:1, 2:1 and 3:1 (CMW:AMD). Acid mine drainage was used as a source of Fe and Al. The CMW/AMD mixtures were then treated with FA at a liquid to solid ratio of 2:1 by stirring with an overhead stirrer. Aliquot samples were collected at $\mathrm{pH} 6,8,9,10,11$ and 12, filtered through a $0.45 \mathrm{~lm}$ nucleopore filter membrane and then analyzed using IC, ICP-AES and ICP-MS. The ICP-AES and ICP-MS samples were acidified to $\mathrm{pH}<3$ using concen- trated $\mathrm{HNO}_{3}$ to stabilize the cations. All the samples were stored at $4{ }^{\circ} \mathrm{C}$ before analysis. The solid residues formed after treatment of CMW and CMW/AMD mixtures with FA were analyzed using quantitative XRD to 
understand the amount of the new mineral phases.

\subsection{Geochemical modelling}

The mineral phases that were likely to form during treatment of CMW and CMW/AMD mixtures were predicted using PHREEQC geochemical modelling code and the WATEQ4F database (Park-hurst and Appelo, 1999). The WATEQ4F database was edited to include the thermodynamic parameters of ettringite as calculated by Perkins and Palmer (1999). Saturation indices (SI) were calculated at different final $\mathrm{pH}$ values by PHREEQC.

$$
S I=\frac{\log I A P}{K_{S p}}
$$

where IAP is the ion activity product observed in solution, and $\mathrm{K}_{\mathrm{sp}}$ is the solubility product.

Positive SI values indicate that a solution is supersaturated with respect to that particular mineral phase, a negative SI value indicates under saturation and a saturation index of zero indicates saturation with respect to a particular mineral. Super saturation and saturation indicate that precipitation of the respective mineral phase is thermodynamically possible. Equilibrium of the solid mineral phase with its ionic components is indicated by SI of zero. Solutions under saturated with respect to a given solid phase suggest that the phase dissolves in solution to its ionic components. Geochemical calculations performed using computer codes do not prove the presence or absence of a phase, but provide an indication of the tendency for a reaction to occur.

\section{Results and discussion}

The chemical compositions of the CMW and AMD samples are shown in Table 1. The major ions of the CMW are $\mathrm{Ca}, \mathrm{Mg}$ and sulphate.

Table 1

Composition of circumneutral mine water and acid mine drainage. $a$ 


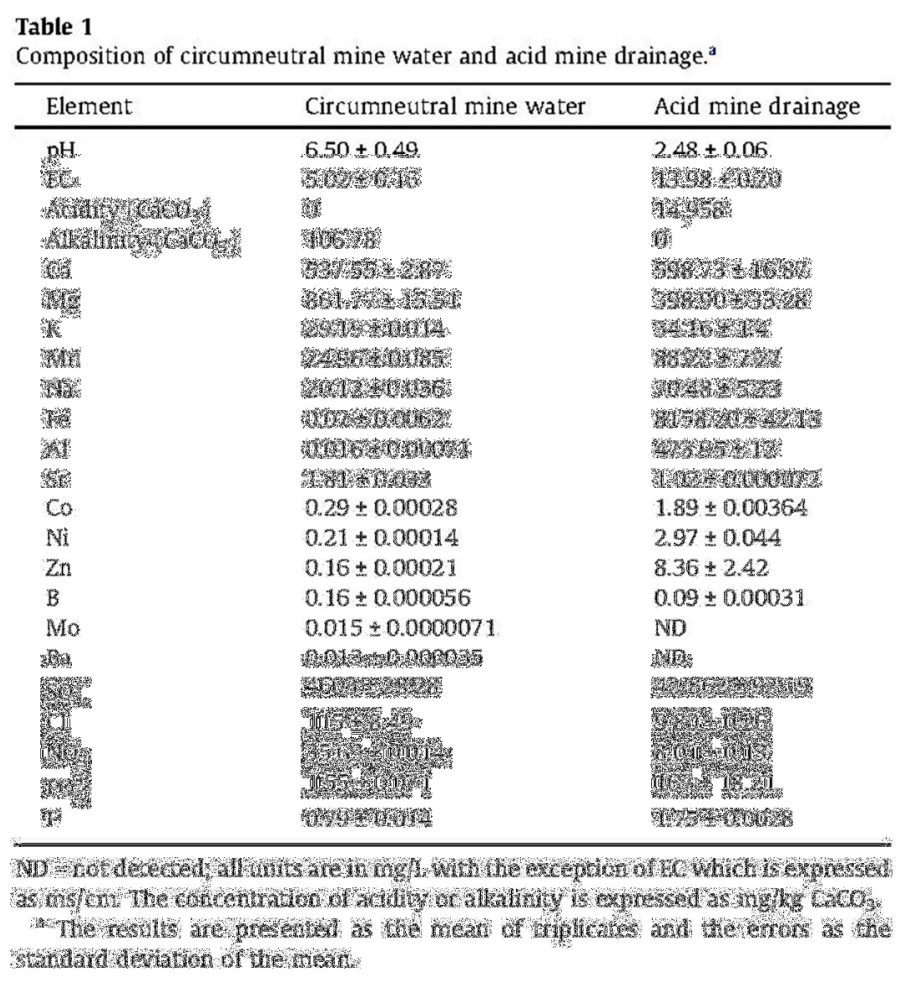

Circumneutral mine water also contains substantial amounts of Mn but very low concentration of $\mathrm{Fe}$ and $\mathrm{Al}$. The AMD contains substantial amounts of $\mathrm{Fe}, \mathrm{Al}$ and Mn. Its sulphate content is far greater than that of the CMW.

The FA mineral composition was analyzed using XRD and results obtained are as depicted in Fig. 1. The FA is composed of mullite $\left(3 \mathrm{Al}_{2} \mathrm{O}_{3}-2 \mathrm{SiO}_{2}\right)$, quartz $\left(\mathrm{SiO}_{2}\right)$, hematite $\left(\mathrm{Fe}_{2} \mathrm{O}_{3}\right)$ and lime $(\mathrm{CaO})$. The SEM images showed (Fig. 1) that FA is typically composed of irregular and numerous spherical shaped particles having an average diameter of less than $10 \mathrm{~lm}$.

The elemental composition of FA was also determined using XRF and the results are shown in Table 2.

Based on the XRF data obtained, the FA used in this study is Class F according to the American Society for Testing and Measure- ment (ASTM C618) classification since $\mathrm{SiO}_{2}+\mathrm{Al}_{2} \mathrm{O}_{3}+\mathrm{Fe}_{2} \mathrm{O}_{3}=86.99 \%>70 \%$. Class $\mathrm{F}$ fly ash is formed during the combustion of either bituminous or anthracitic type of coal (Mattigod et al., 1990).

\subsection{Effect of the final $p H$}

After addition of FA to $\mathrm{CMW}$ the $\mathrm{pH}$ changed rapidly such that after $20 \mathrm{~min}$ the $\mathrm{pH}$ had reached 12.35 after which it remained constant. The results reveal that the concentration of sulphate, $\mathrm{Mg}$ and $\mathrm{Mn}$ removed from the CMW depends on the final $\mathrm{pH}$ of the water (Fig. 2). Also Fig. 2b shows that the amount of Ca increases 
with increase in the final $\mathrm{pH}$. Treatment of mine water to $\mathrm{pH} 9.88$ removes $6 \%$ of sulphate from mine water. Treatment of the mine water to a $\mathrm{pH}$ of 12.35 results in $71 \%$ of sulphate being removed from mine water (Fig. 2a).

The XRD results obtained for FA and solid residues (SR) taken at $\mathrm{pH} 11.77$ and 12.34 show that the only new mineral phase formed during treatment of mine water with FA was gypsum (Fig. 3). This means that the sulphate is being removed in the form of gypsum during the treatment of mine water with FA. The $\mathrm{CaO}$ in FA leaches into the mine water causing the $\mathrm{pH}$ and the Ca concentration to in- crease (Fig. 2). This resulted in the disappearing of the lime peaks in the solid residue XRD spectra (Fig. $3)$.

A comparison of the elemental composition of FA and solid residues (SR) shows that the $\% \mathrm{SO}_{3}, \mathrm{MnO}$ and $\mathrm{MgO}$ increases in the $\mathrm{SR}$ as the final $\mathrm{pH}$ end point was increased (Table 3). This correlates well with the results obtained from cation and anion analysis which showed a decrease in the sulphate, $\mathrm{Mn}$ and $\mathrm{Mg}$ concentration of the water as the final $\mathrm{pH}$ increased (Fig. 2).

The percentage composition of $\mathrm{CaO}$ increased from fresh FA to $\mathrm{pH} 9.88$ and then decreased slightly in the solid residue as the final

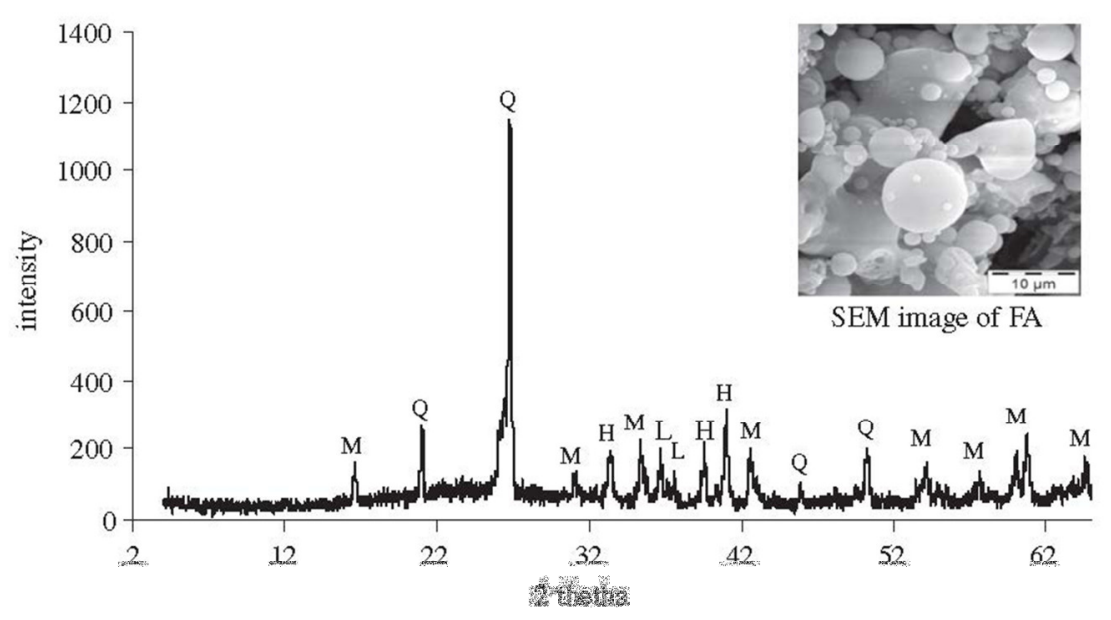

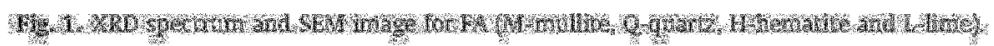




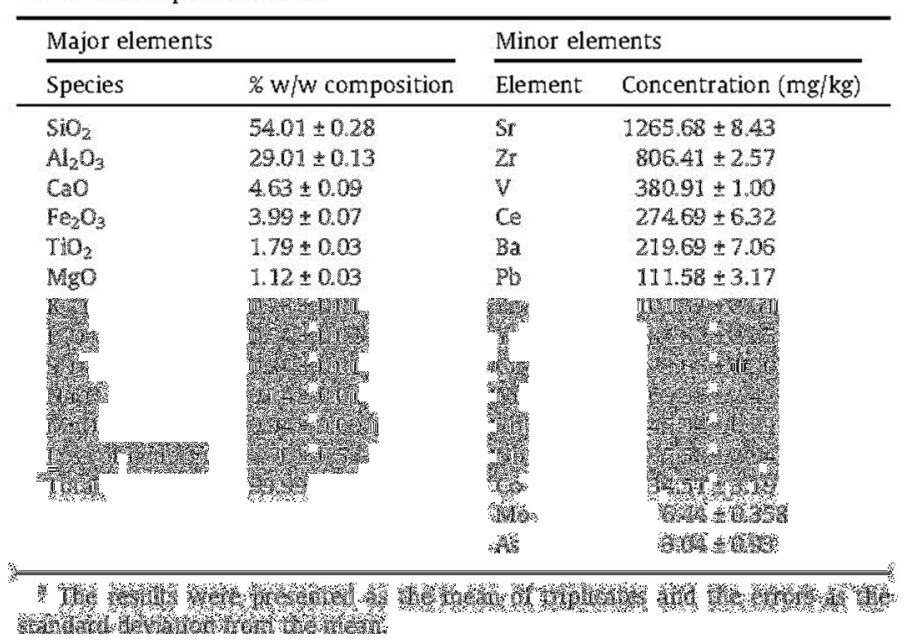

$\mathrm{pH}$ was further increased and this correlates with an increase in Ca concentration (Fig. 2b). During treatment of mine water with FA, lime from FA dissolves into solution thereby causing the $\mathrm{pH}$ of the water to increase (Eq. (3)). As the final pH of process water is increased, more $\mathrm{CaO}$ is available in the mine water (Eq. (3)) and more $\mathrm{Ca}^{2+}$ ions are present, causing Eq. (4) to shift to the right according to Le Chatelier's principle, resulting in enhanced removal of sulphate as gypsum (Fig. 2a).

$$
\begin{aligned}
& \mathrm{CaO}+\mathrm{H}_{2} \mathrm{O} \rightarrow \mathrm{Ca}^{2+}+2 \mathrm{OH} \text { (3) } \\
& \mathrm{Ca}^{2+}+\mathrm{SO}_{4}^{2}+2 \mathrm{H}_{2} \mathrm{O} \rightarrow \mathrm{CaSO}_{4} \cdot 2 \mathrm{H}_{2} \mathrm{O}(4)
\end{aligned}
$$

The results obtained have shown that the removal of sulphates, $\mathrm{Mg}$ and $\mathrm{Mn}$ from CMW is dependent of $\mathrm{pH}$. Approximately $71 \%$ of sulphate can be removed when the $\mathrm{pH}$ is increased from 6.5 to greater than 11, while almost $100 \%$ of $\mathrm{Mn}$ and $\mathrm{Mg}$ could be removed when the $\mathrm{pH}$ is increased beyond 9 and 11 respectively.

\subsection{Effect of Fe and Al on sulphate removal}

The 1:0, 1:1, 2:1 and 3:1 CMW and AMD mixtures had pH values of 6.5, 2.3, 2.65 and 2.63 before adding FA respectively. The 1:0 mixture was purely CMW, while 1:1, 2:1 and 3:1 had AMD characteristics. The AMD characteristics are more pronounced in the 1:1 mixture followed by 2:1 and lastly 3:1. The converse is true for CMW characteristics. The mixtures were treated with FA and the $\mathrm{pH}$ profiles over time of different mixtures are as shown in Fig. 4.

As observed in Fig. 4, the treatment of CMW with FA resulted in a rapid change in $\mathrm{pH}$ from 6.5 to 12.35 with a buffering plateau at $\mathrm{a} \mathrm{pH} 10$, which was not as prominent for the CMW/AMD mixtures. The buffering plateau at $\mathrm{pH} 10$ is ascribed to the hydrolysis of $\mathrm{Mn}^{2+}$ (Eq. (5)) and oxidation and precipitation of $\mathrm{Mn}^{2+}$ (Eq. (6)) (Younger et al., 2002). The higher $\mathrm{Mn}^{2+}$ concentration in the CMW/AMD 
mixtures has resulted in a more prominent buffering plateau at $\mathrm{pH} 10$ compared $\mathrm{t}^{469}$ CMW trend.

$\mathrm{Mn}^{2+}+2 \mathrm{H}_{3} \mathrm{O} \rightarrow \mathrm{Mn}(\mathrm{OH})_{2}+2 \mathrm{H}^{+}$

$\mathrm{Mn}^{3}+\frac{1}{4} \mathrm{O}_{2}+\mathrm{H}_{2} \mathrm{O} \rightarrow \frac{1}{2} \mathrm{Mn}_{2} \mathrm{O}_{3}+2 \mathrm{H}^{+}$

The $\mathrm{pH}$ trends for the 3:1, 2:1 and 1:1 mixtures show gradual changes with multiple buffering plateaus. The buffering at $\mathrm{pH}$ 6-6.5 can be attributed to the hydrolysis of $\mathrm{Fe}$ and $\mathrm{Al}$ that was introduced as a result of mixing AMD with CMW (Eqs. (7) and (8)).
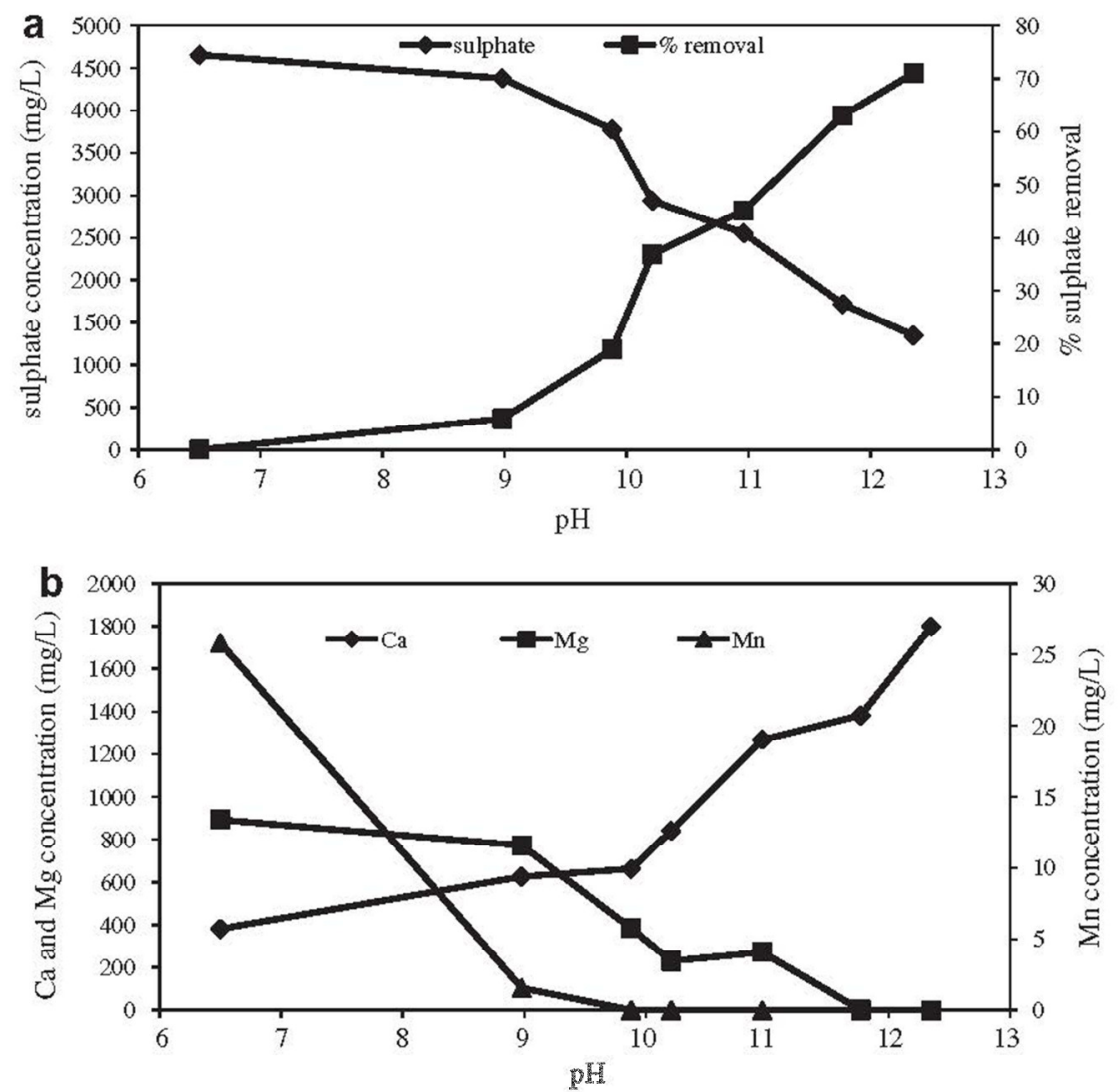

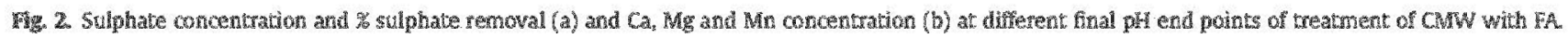




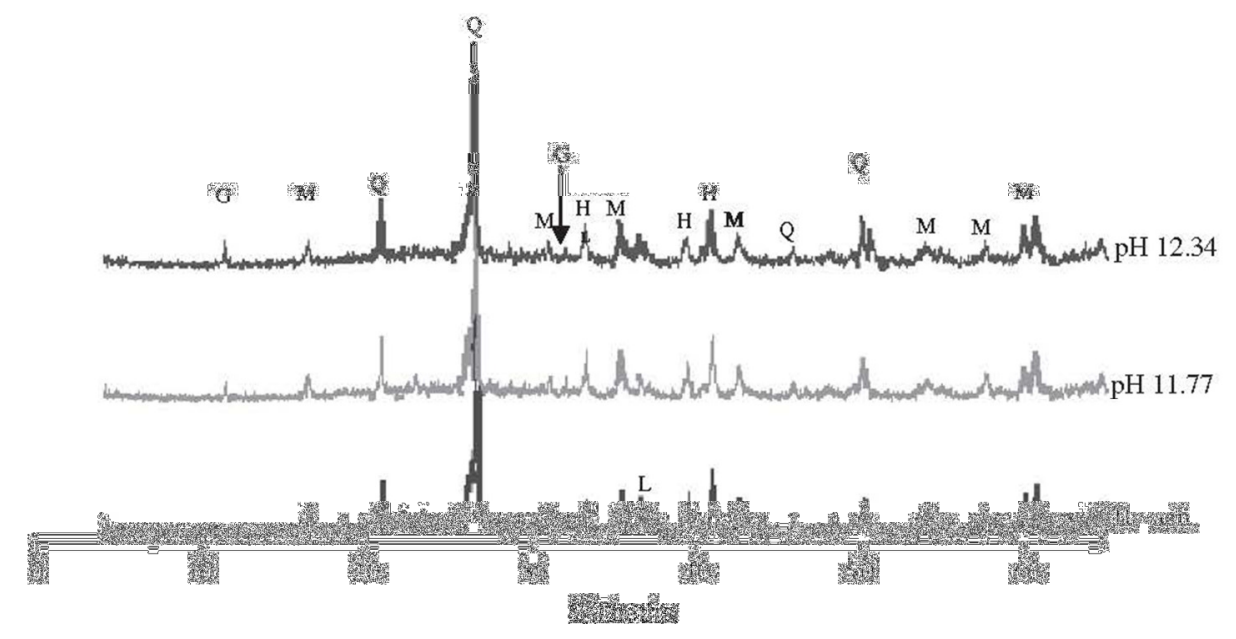

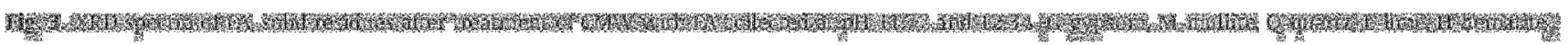

Tabios 3

Elementail composition of FA and solid residues at different pH values of treatment.

\begin{tabular}{|c|c|c|c|c|c|}
\hline$x$ Oxide & Fresh FA & pH 9.88 & pH 10.2I & $\mathrm{pH} 11.77$ & $\mathrm{pH} 1234$ \\
\hline \&) & 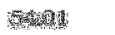 & 海e & 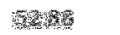 & Kar & אน: \\
\hline rind & 28 & (6) & 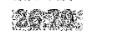 & 26x & 246 \\
\hline cara & 3. & 47 & 14ted & When & 1.66 \\
\hline 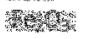 & 28 & $x-16$ & 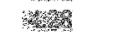 & 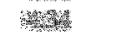 & \% \\
\hline Who & 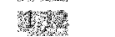 & W & 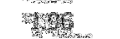 & 3.82 & 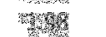 \\
\hline $\mathrm{TO}_{2}$ & 1.79 & 1.475 & 3.459 & 1.440 & 2.49 \\
\hline $\mathrm{K}_{2} \mathrm{O}$ & 0.78 & 0.75 & 0.74 & 0.73 & 0.74 \\
\hline $\mathrm{SO}_{3}$ & 0.24 & 0.70 & 0.71 & $1.2 \mathrm{~A}$ & 1.30 \\
\hline $\mathrm{P}_{2} \mathrm{O}_{5}$ & 0.54 & 0.535 & 0.531 & 0.525 & 0.529 \\
\hline $\mathrm{Na}_{2} \mathrm{O}$ & 0.12 & 0.03 & 0.06 & 0.08 & 0.07 \\
\hline MnO & 0.04 & 0,053 & 0.060 & 006 & 0.06 \\
\hline Lor & 3.7 & 4882 & 4820 & 4953 & 487 \\
\hline Tatal & 9999 & 99.40 & $98.8 \mathrm{~A}$ & 9914 & 9998 \\
\hline
\end{tabular}

Tave 3

Elemental composition of FA and solid residues at different $\mathrm{pH}$ values of treatment.

\begin{tabular}{|c|c|c|c|c|c|}
\hline *xide & Fresh FA & pH 9.88 & $\mathrm{pH} 1021$ & pH 11.77 & $\mathrm{pH} 12.34$ \\
\hline $6_{102}$ & Whet & 5 & 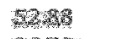 & 127\% & *3240 \\
\hline 240 & 201 & 269 & $26 \pi \%$ & $26 \times$ & $26 \times 5$ \\
\hline Cac & itos & Ars & 468 & (4) & 356 \\
\hline Nor 0 & $19 \times 99$ & s. & West & Hexte & 4 \\
\hline Nyo: & W19 & 188: & $14 \times 2$ & अ: & ageng \\
\hline $\mathrm{THO}_{2}$ & 1.79 & 1.475 & 1.459 & 1.440 & 1.49 \\
\hline $\mathrm{K}_{2} \mathrm{O}$ & 0.78 & 0.75 & 0.74 & 0.73 & 0.74 \\
\hline $\mathrm{SO}_{3}$ & 0.24 & 0.70 & 0.71 & 1.24 & 1.30 \\
\hline $\mathrm{P}_{2} \mathrm{O}_{5}$ & 0.54 & 0.535 & 0.531 & 0.525 & 0.529 \\
\hline $\mathrm{Na}_{2} \mathrm{O}$ & 0.14 & 0.03 & 0.06 & 0,08 & 0.07 \\
\hline $\mathrm{MnO}$ & 0.04 & 0.063 & 0.060 & 0.06 & 0.06 \\
\hline LOI & 3.7 & 4.882 & 4820 & 4953 & 4.87 \\
\hline Total & 99.99 & 99.40 & 98.84 & 99.14 & 99.98 \\
\hline
\end{tabular}

Moreover, the buffering between $\mathrm{pH} 4$ and 7 can be attributed to the precipitation of $\mathrm{Fe}$ and $\mathrm{Al}$ hydroxides: $\mathrm{Fe}(\mathrm{OH})_{3}, \mathrm{Fe}(\mathrm{OH})_{2}$ and $\mathrm{Al}(\mathrm{OH})_{3}$ (Uhlmann et al., 2004; Jenke and Gordon, 1983). 


$$
\begin{aligned}
& \mathrm{Fe}^{3+}+3 \mathrm{H}_{2} \mathrm{O} \rightarrow \mathrm{Fe}(\mathrm{OH})_{3}+3 \mathrm{H}^{+} \\
& \mathrm{Al}^{3+}+3 \mathrm{H}_{2} \mathrm{O} \rightarrow \mathrm{Al}(\mathrm{OH})_{3}+3 \mathrm{H}^{+}
\end{aligned}
$$

The precipitation of oxy-hydroxysulphate consumes alkalinity thereby causing $\mathrm{pH}$ buffering according to Eqs. (9)-(11). According to Younger et al. (2002) the precipitation of the oxyhydroxysul- phate occurs between $\mathrm{pH} 4$ and 9.
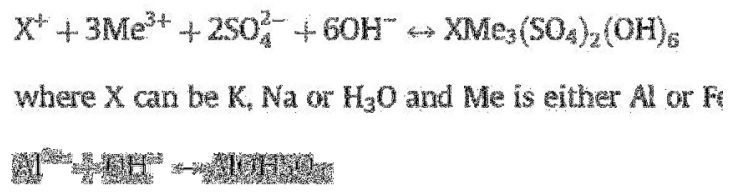

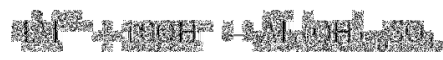

Sulphate removal as function of $\mathrm{pH}$ for different CMW/AMD mixtures is shown in Fig. 5 .

The sulphate concentration for the CMW (1:0) was reduced from $4655 \mathrm{mg} / \mathrm{L}$ to $4381 \mathrm{mg} / \mathrm{L}$ when CMW was treated with FA to $\mathrm{pH} 10$, which is approximately $19 \%$ sulphate removal. In the case of the mixtures; the sulphate concentration of 3:1 CMW/AMD mixture was reduced from $15797 \mathrm{mg} / \mathrm{L}$ to $2731 \mathrm{mg} / \mathrm{L}$, for 2:1 CMW/ AMD mixture the sulphate concentration was reduced from 17142 $\mathrm{mg} / \mathrm{L}$ to $2435 \mathrm{mg} / \mathrm{L}$ and for the $1: 1$ mixture the sulphate concentration was reduced from 20870 to $1970 \mathrm{mg} / \mathrm{L}$ when the mixtures were treated with FA to $\mathrm{pH}$ 10. This translates to more than 80\% sulphate removal when 3:1, 2:1 and 1:1 mixtures were treated with FA to $\mathrm{pH}$ 10. It can be concluded from the above set of experiments that the presence of $\mathrm{Fe}$ and $\mathrm{Al}$ in mine water has enhanced the sulphate removal.

The small sulphate removal observed for CMW when treated with FA to $\mathrm{pH} 10$ was because the $\mathrm{pH}$ rise only required a very small amount of $\mathrm{CaO}$ to be released from FA due to the absence of Fe and $\mathrm{Al}$ to buffer the sharp rise in $\mathrm{pH}$ (Fig. 4). This resulted in small amounts of Ca2+ being released into solution to react and precipitate out to form gypsum (Eq. (4)). 


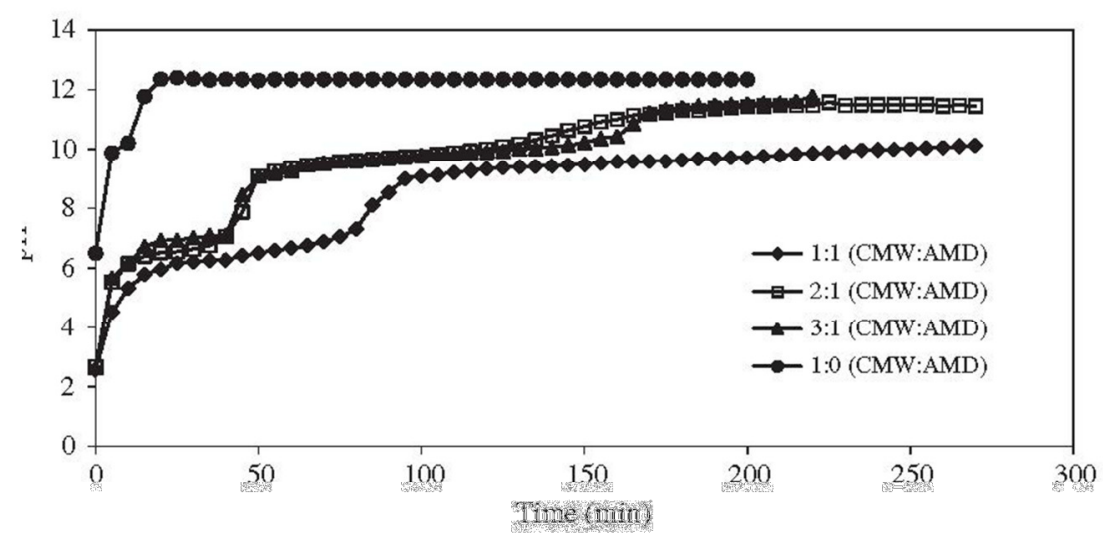

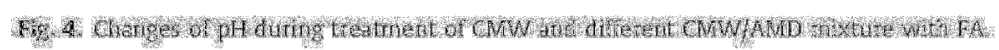

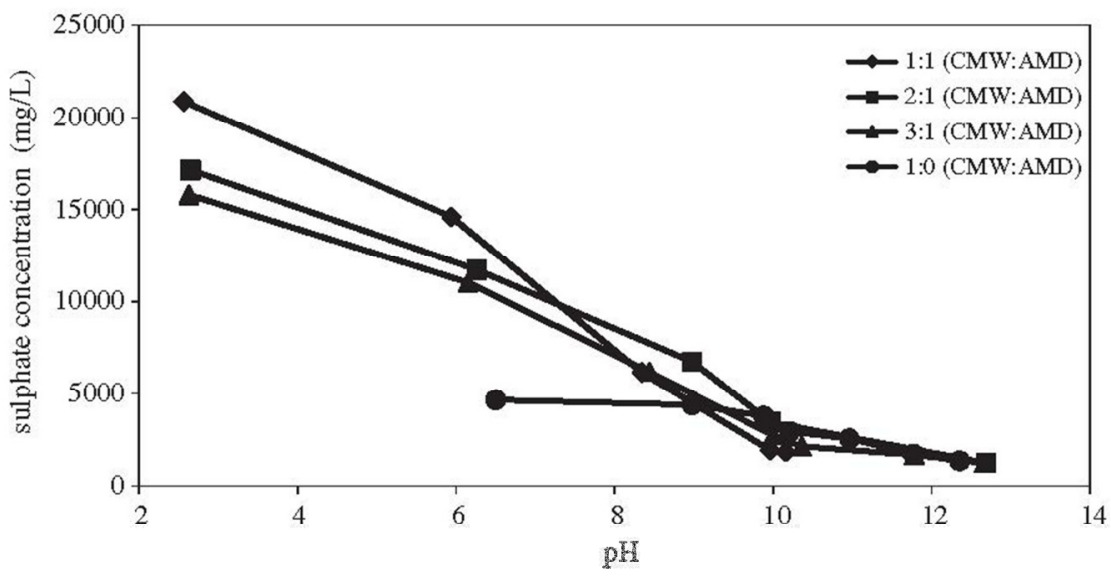

Fig 5. Sulphate concentration during treatment of $\mathrm{CMW}$ and different CMW/AMD mixtures with FA.

Table 4

The peroentage composition of the mineral phases in fly ash and solid residues produced after treatment of CMW and CMWIAMD.

\begin{tabular}{|c|c|c|c|}
\hline Minetals (2) & Fly ash & $\begin{array}{l}\text { CMW solid } \\
\text { residue }\end{array}$ & $\begin{array}{l}\text { CMW/AMD } \\
\text { solid residue }\end{array}$ \\
\hline 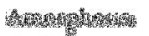 & 的的 & 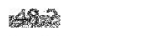 & mas \\
\hline 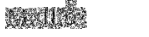 & 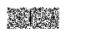 & 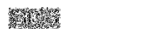 & 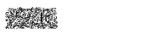 \\
\hline Wester & 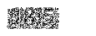 & 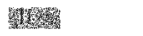 & 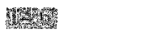 \\
\hline 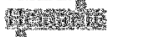 & 25 & 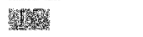 & D埾 \\
\hline 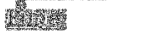 & 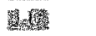 & nf & 㺒 \\
\hline 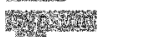 & 触 & 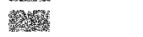 & 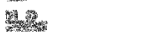 \\
\hline
\end{tabular}



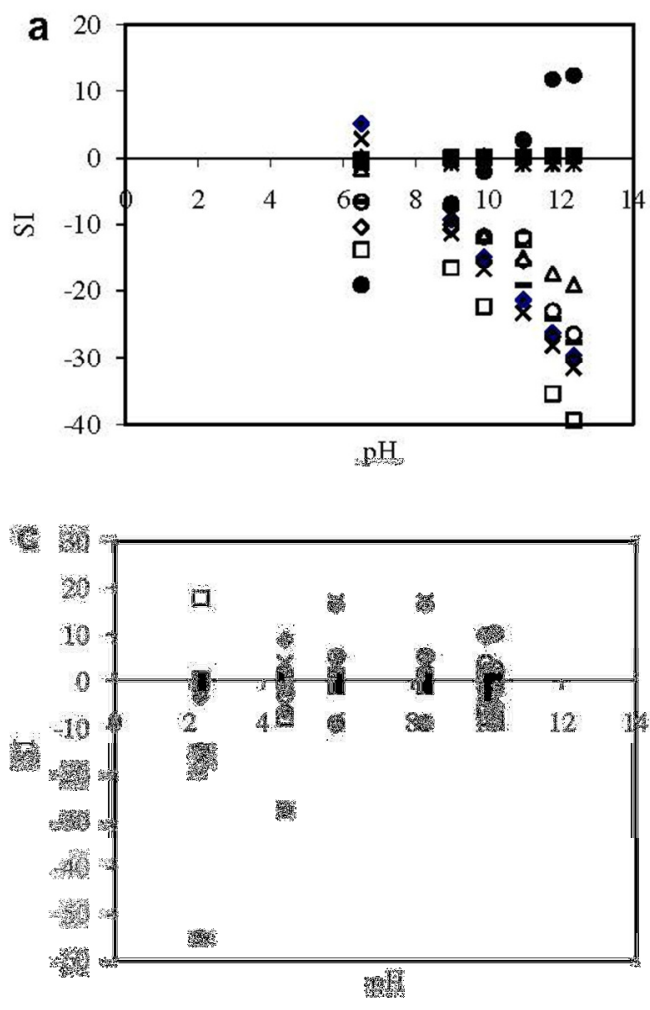
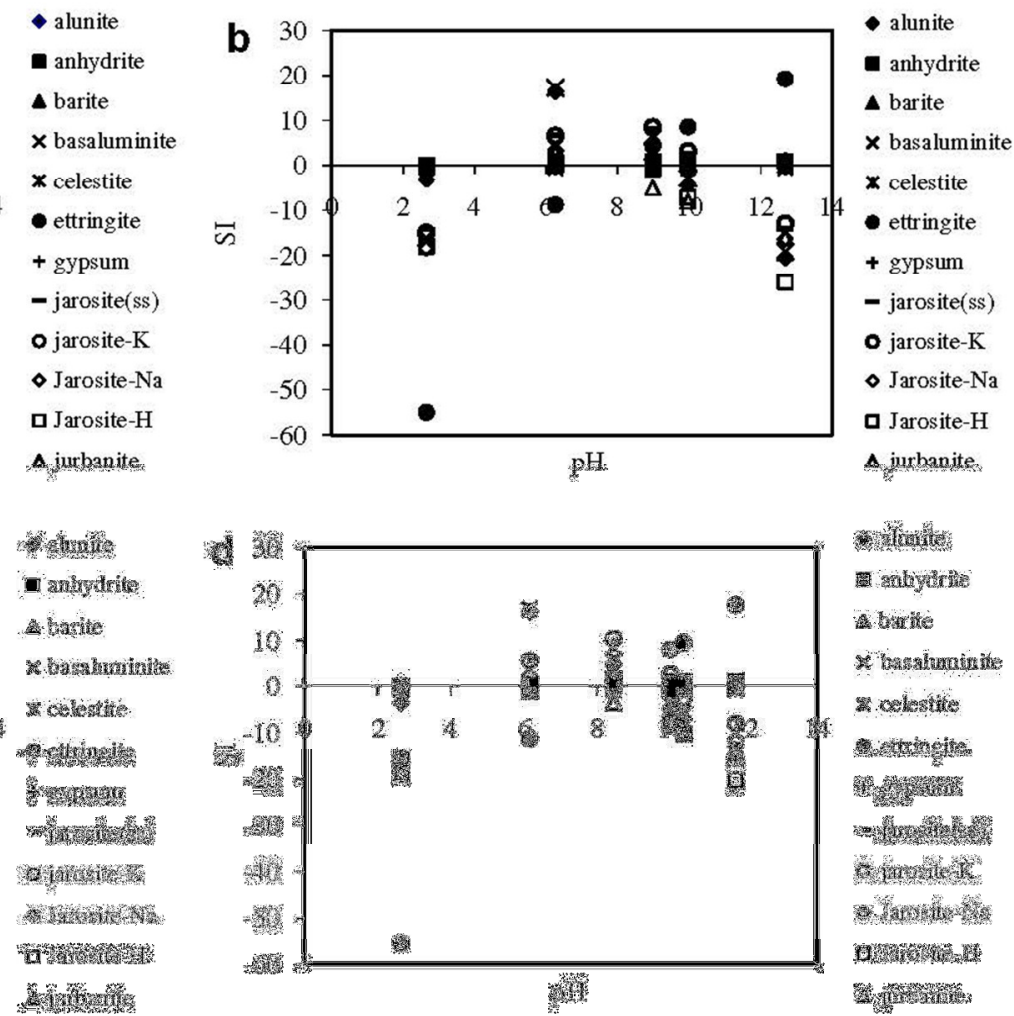

Fig. 6. Saturation indices of sulphate mineral phases at different final pH for treatment of CMW (a) and CMW/AMD mixtures (b-1:1, c-2:1 and d-3:1) with FA. Saturation index $<0$ means under saturation, saturation index $=0$ means saturation and saturation index $>0$ means super saturation. Supersaturation and saturation with respect to a particular mineral means precipitation of that mineral can occur.

The qualitative XRD spectra for the solid residues produced during treatment of AMD or CMW with FA showed similar spectra to those in Fig. 3. Quantitative XRD was conducted in order to see the difference of the changes in the amount of new minerals that were formed during treatment of AMD or CMW with FA (Table 4).

The results showed that the new mineral phase after treatment of mine water with FA is gypsum. The appearance of gypsum occurs as lime disappears, meaning that the $\mathrm{Ca}$ that leaches as a result of the dissolution of lime (resulting in a $\mathrm{pH}$ increase as depicted in Fig. 4), reacts with the sulphates in the mine water to form gypsum (Eq. (4)). More gypsum was formed in the solid residues produced from FA that was used to treat CMW/AMD mixtures because more lime had to leach to offset the $\mathrm{pH}$ buffering caused by the presence of $\mathrm{Fe}$ and $\mathrm{Al}$ (Eqs. (7)-(11)). Other mineral phases that were formed were amorphous as shown by the in-crease in the percentage in the solid residue. The identity of these amorphous mineral phases was elucidated using PHREEQC geo-chemical modelling.

\subsubsection{PHREEQC geochemical modeling}

The possible sulphate mineral phases that were precipitating at different $\mathrm{pH}$ levels were predicted 
using PHREEQC thermodynamic geochemical model and the results are shown in Fig. 6. The ${ }^{1}$ saturation indices (SI) obtained by PHREEQC geochemical modelling predicted the following sulphate-bearing mineral phases; ettringite $\left(\mathrm{CaO}-3 \mathrm{CaSO}_{4}-\mathrm{Al}_{2} \mathrm{O} 3-31 \mathrm{H} 2 \mathrm{O}\right)$; alunite $\left(\mathrm{KAl}_{3}\left(\mathrm{SO}_{4}\right) 2(\mathrm{OH}) 6\right)$, anhydrite $\left(\mathrm{CaSO}_{4}\right)$, barite $\left(\mathrm{BaSO}_{4}\right)$, basaluminite $\left(\mathrm{Al}_{4}(\mathrm{OH}) \mathrm{OSOSO}_{4}\right)$, jurbanite(AlOHSO 4$),$ jarosite-ss $\left(\mathrm{Ko.77}_{4} \mathrm{NaO} . \mathrm{O}_{3} \mathrm{Ho}_{2} \mathrm{Fe}_{3}\left(\mathrm{SO}_{4}\right)_{2}(\mathrm{OH}) 6\right)$, jarosite-K $\left(\mathrm{KFe}_{3}\left(\mathrm{SO}_{4}\right)_{2}(\mathrm{OH}) 6\right), \quad$ jarosite- $\mathrm{Na} \quad\left(\mathrm{NaFe}_{3}\left(\mathrm{SO}_{4}\right)_{2}(\mathrm{OH}) 6\right), \quad$ jarosite- $\mathrm{H}$ $\left(\mathrm{H}_{3} \mathrm{OFe}_{3}\left(\mathrm{SO}_{4}\right)_{2}(\mathrm{OH}) 6\right)$, celestite $\left(\mathrm{SrSO}_{4}\right)$ and gypsum $\left(\mathrm{CaSO}_{4}-2 \mathrm{H}_{2} \mathrm{O}\right)$ to be precipitating at various $\mathrm{pH}$ values (Fig. 6).

Saturation indices of different sulphate-bearing mineral phases for CMW/FA mixtures at different $\mathrm{pH}$ end points (Fig. 6a) show that gypsum, barite, celestite, anhydrite and ettringite are the only mineral phases that could precipitate out sulphate when CMW was mixed with FA. The amount of sulphate that could be removed as ettringite, barite and celestite was insignificant since the concentration of $\mathrm{Al}, \mathrm{Ba}$, and $\mathrm{Sr}$ was in $\mathrm{CMW}$.

Saturation indices calculated for the 3:1, 2:1 and 1:1 CMW/ AMD mixtures (Fig. 6b-d) using PHREEQC geochemical software show that, in addition to gypsum, celestite, ettringite and anhydrite, other $\mathrm{Fe}$ and $\mathrm{Al}$ oxyhydroxysulphates (alunite, basaluminite, jarosite(ss), jarosite-k, jarosite- $\mathrm{Na}$, jarosite- $\mathrm{H}$ and jurbanite) can contribute to sulphate removal. All the oxyhydroxysulphates are super saturated at $\mathrm{pH}$ 4-10 except ettringite. Above $\mathrm{pH} 10$ they become under saturated and ettringite becomes supersaturated. This explains why the 3:1, 2:1 and 1:1 CMW/AMD mixtures tend to precipitate out more sulphate compared to CMW when $\mathrm{pH}$ was raised to below 10 as the removal of sulphate is not as pronounced for AMD after $\mathrm{pH} 10$ as compared to below $\mathrm{pH} 10$ and the converse is true for CMW. 


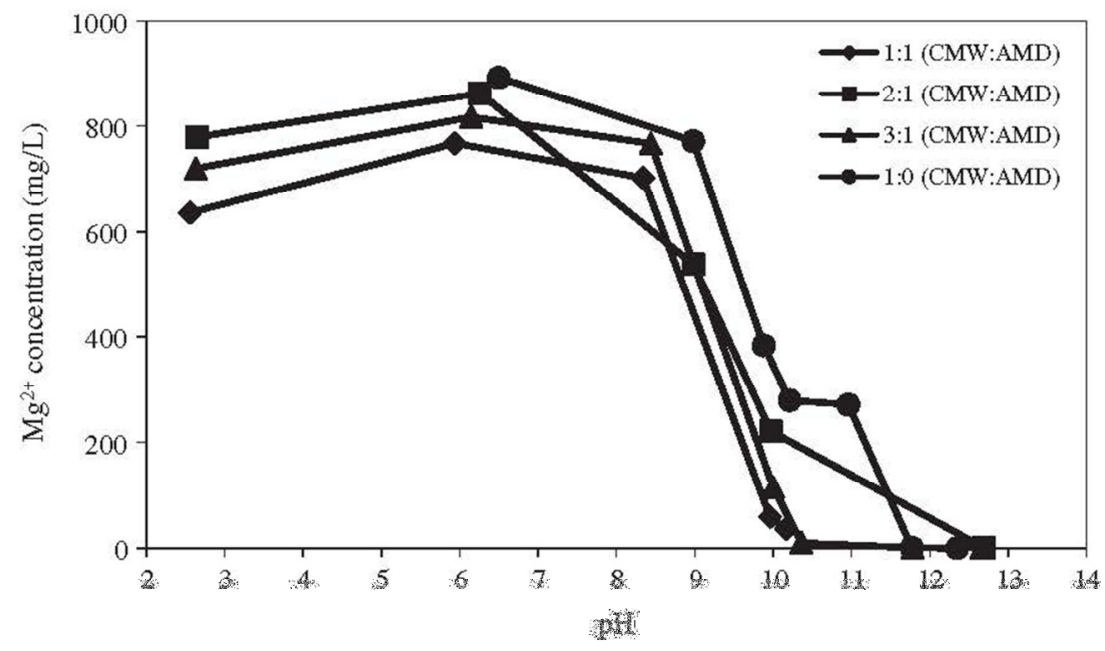

W.
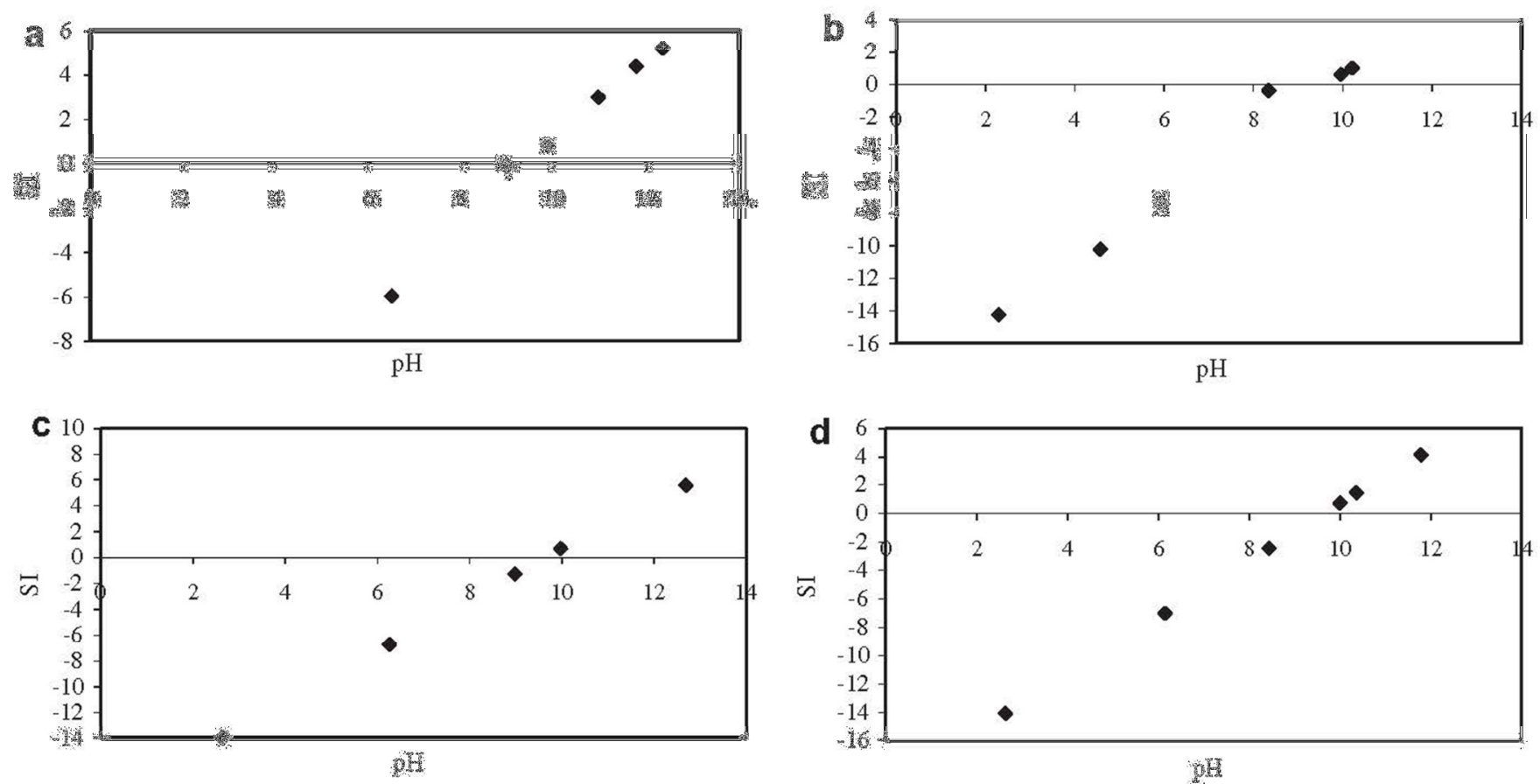

Fig. 8. Saturation indices of brucite at different final pH end points during treatment of CMW (a) and CMW/AMD mixtures (b-1:1, C-2:1 and d-3:1) with FA. Saturation index $<0$ means under saturation, saturation index $=0$ means saturation and saturation index $>0$ means super saturation. Super saturation and saturation with respect to a particular mineral means precipitation of that mineral can occur.

The presence of $\mathrm{Fe}$ and $\mathrm{Al}$ ions generates acidity $\left(\mathrm{H}^{+}\right.$ions) as $\mathrm{Al}$ and $\mathrm{Fe}$ (oxy) ydroxides precipitate according to Eqs. (7) and (8). Precipitation of oxyhydroxysulphates consumes alkalinity as shown in Eqs. (9)-(11) (Younger et al., 2002). The acidity generated by hydrolysis reactions during the precipitation of $\mathrm{Al}$ and $\mathrm{Fe}$ (oxy)hydroxides and the consumption of alkalinity during precipitation of oxyhydroxysulphates facilitates dissolution of more $\mathrm{CaO}$ for $\mathrm{pH}$ to increase to 10 , releasing more $\mathrm{Ca}^{2+}$ ions. The $\mathrm{Ca}^{2+}$ ions combine with sulphate to form gypsum leading to removal of $\mathrm{SO}^{2-}$. Precipita- tion of $\mathrm{Al}, \mathrm{Fe}$ (oxy)hydroxides and oxyhydroxysulphates in addition to gypsum precipitation thereby contributes to 
more sulphate removal through adsorption and structural incorporation of $\mathrm{SO}^{2^{41}}$ .Treatment of CMW and all the mixtures of CMW/AMD to $\mathrm{pH}$ levels beyond $\mathrm{pH} 10$ show similar trends of sulphate removal (Fig. 6). This is because the sulphate phases that are supersaturated above $\mathrm{pH} 10$ and hence responsible for sulphate removal are; barite, ettringite, gypsum and anhydrite for CMW and all CMW/AMD mixtures.

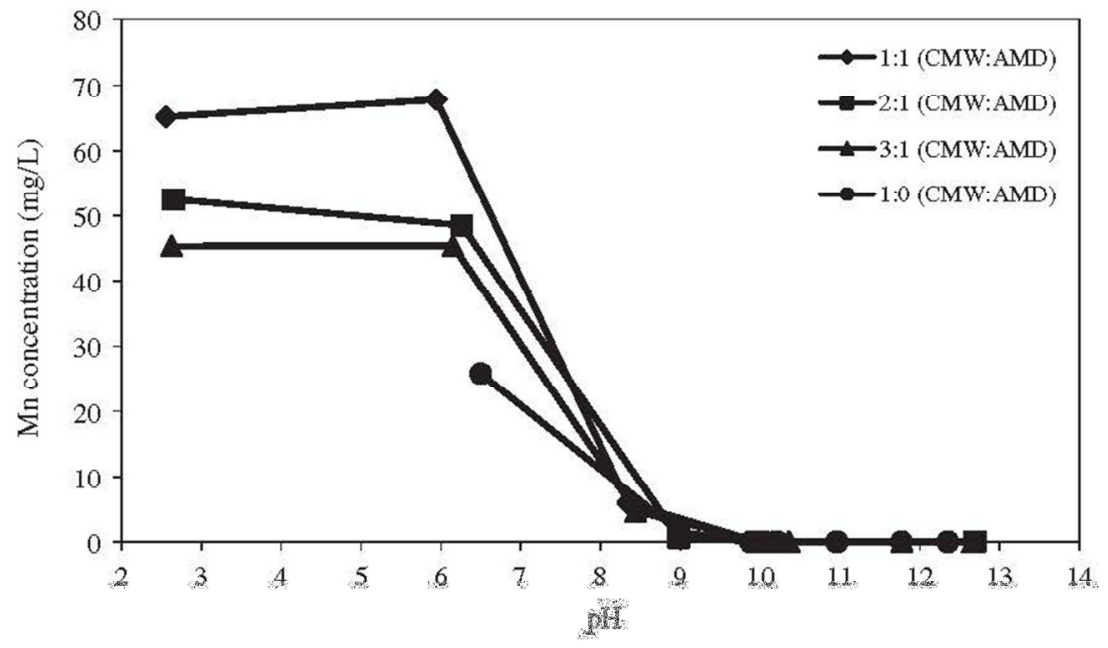

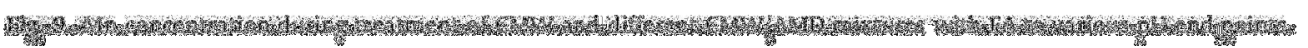
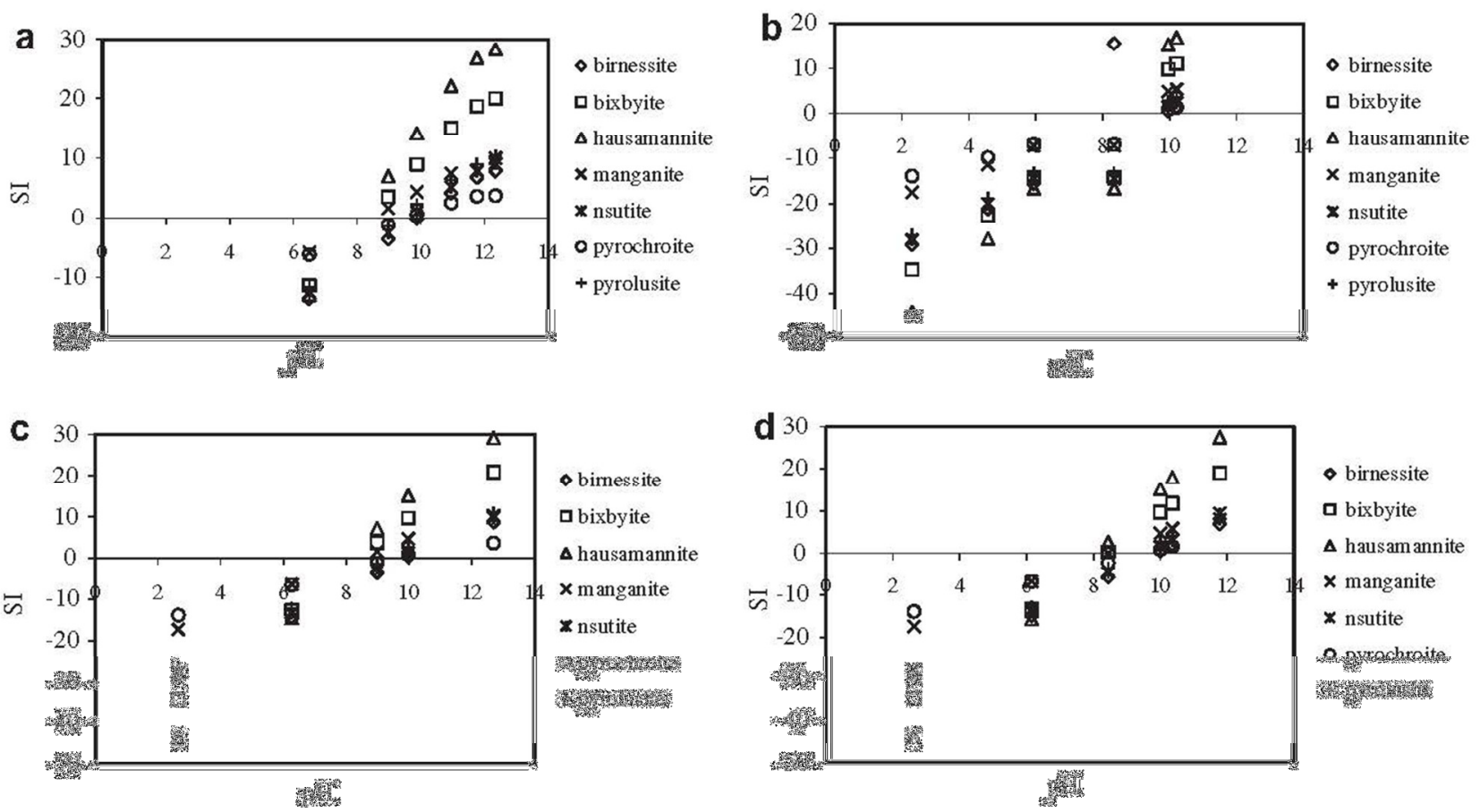

Fig. 10. Saturation indices of Mn bearing minerals phases at different final pH end points during treatment of CMW (a), CMW/AMD mixtures ( $b-1: 1, C-2: 1$ and d-3:1) with FA. Saturation index $<0$ means under saturation, saturation index $=0$ means saturation and saturation index $>0$ means super saturation. Super saturation and saturation with respect to a particular mineral means precipitation of that mineral can occur.

Treatment of CMW and CMW/AMD mixtures with FA results in approximately $100 \%$ removal of $\mathrm{Mg}$ from $600-800 \mathrm{mg} / \mathrm{L}$ to $0.3 \mathrm{mg} / \mathrm{L}$ (Fig. 7). The degree of removal is dependent on the final $\mathrm{pH}$ of treatment. Between $\mathrm{pH} 2$ and 6 a slight increase of $\mathrm{Mg}$ concentration is observed because of the dissolution of $\mathrm{Mg}$ salts from $\mathrm{FA}$, at $\mathrm{pH} 9 \mathrm{Mg}$ 
starts precipitating rapidly and eventually precipitating to below $0.3 \mathrm{mg} / \mathrm{L}$ at $\mathrm{p} \Psi^{1}$ greater than 10 (Fig. 7).

PHREEQC geochemical modelling predicts that $\mathrm{Mg}$ would start to precipitate at $\mathrm{pH}$ greater than 8 (Fig. 8) as brucite $\left(\mathrm{Mg}(\mathrm{OH})_{2}\right)$. The saturation index shows that $\mathrm{Mg}(\mathrm{OH})_{2}$ is saturated when the $\mathrm{pH}$ is approximately 8.5. At $\mathrm{pH}$ above 10, $\mathrm{Mg}(\mathrm{OH})_{2}$ is supersaturated, consequently the $\mathrm{Mg}$ concentration decreased to below $0.3 \mathrm{ppm}$ due to the formation of $\mathrm{Mg}(\mathrm{OH})_{2}$.

The results obtained when CMW and CMW/AMD mixtures when treated with FA show that $\mathrm{Mn}$ is also removed from between 40 and $70 \mathrm{mg} / \mathrm{L}$ to below $0.04 \mathrm{mg} / \mathrm{L}$ (Fig. 9) when the $\mathrm{pH}$ was higher than 8.

Saturation indices obtained using PHREEQC show that Mn-bear- ing mineral phases start precipitating at $\mathrm{pH}$ greater than 8 (Fig. 10) as birnessite $\left(\mathrm{MnO}_{2}\right)$, bixbyite $\left(\mathrm{Mn}_{2} \mathrm{O}_{3}\right)$, hausamannite $\left(\mathrm{Mn}_{3} \mathrm{O}_{4}\right)$, manganite $(\mathrm{MnOOH})$, nsutite $\left(\mathrm{MnO}_{2}\right)$, pyrochroite $\left(\mathrm{Mn}(\mathrm{OH})_{2}\right)$ and pyrolusite $\left(\mathrm{MnO}_{2}\right)$. All these mineral phases approach saturation at $\mathrm{pH} 8.5$ and are supersaturated at $\mathrm{pH}$ greater than 9 , and thus precipitate out rapidly and completely. 


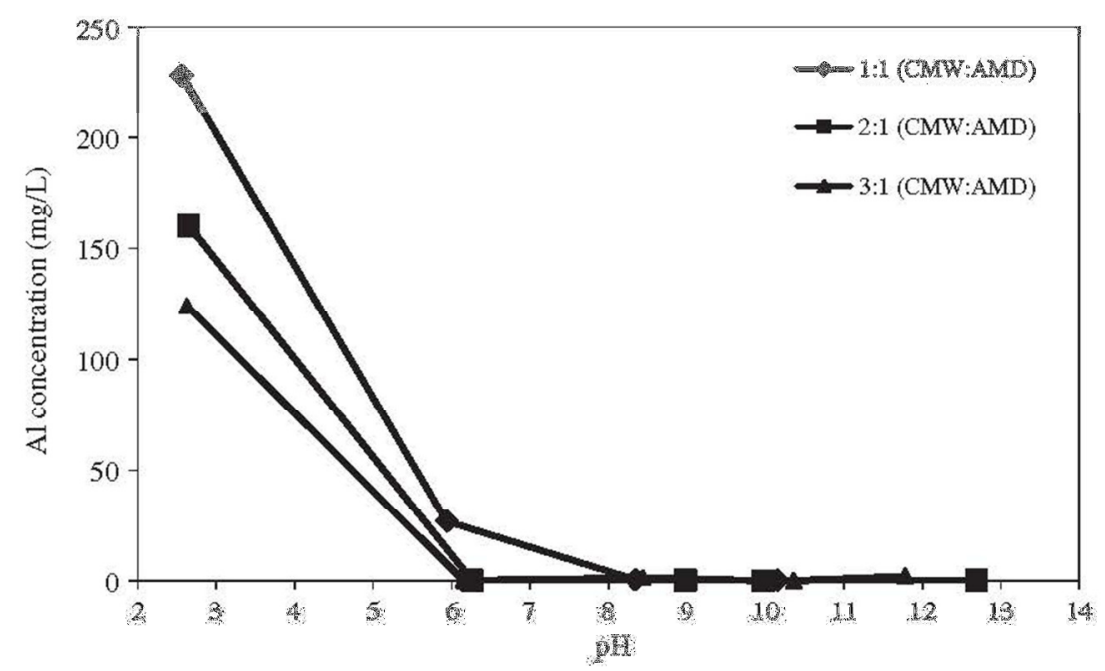

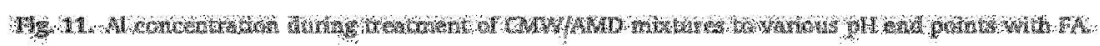
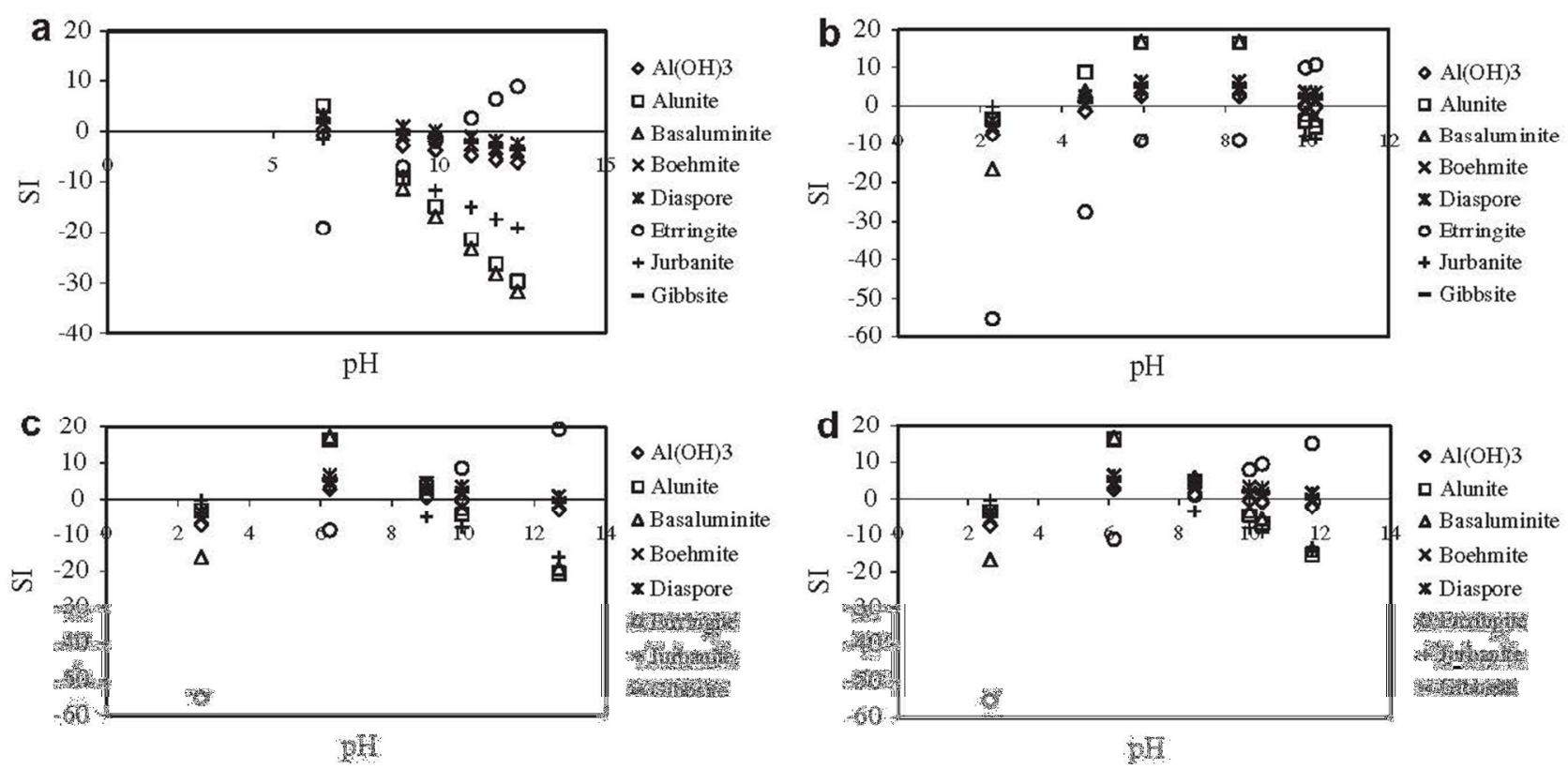

Fig. 12. Saturation indices of Al bearing mineral phases at different pH end points during treatment of CMW (a) and CMW/AMD mixtures (b-1:1, $C-2: 1$ and d-3:1) with FA. Saturation index $<0$ means under saturation, saturation index $=0$ means saturation and saturation index $>0$ means super saturation. Super saturation and saturation with respect to a particular mineral means precipitation of that mineral can occur.

When 3:1, 2:1 and 1:1 CMW/AMD mixtures were treated with FA to various $\mathrm{pH}$ end points the $\mathrm{Al}$ concentration was reduced from between 124 and $228 \mathrm{mg} / \mathrm{L}$ to as low as $48 \mathrm{mg} / \mathrm{L}$ when the $\mathrm{pH}$ was raised to 6 . The $\mathrm{Al}$ concentration further decreased to below $\mathrm{mg} / \mathrm{L}$ when the $\mathrm{pH}$ was raised to above 9 (Fig. 11).

The SI indices were calculated for Al-bearing mineral phases using PHREEQC geochemical model (Fig. 12). The calculated SI indicated that amorphous $\mathrm{Al}(\mathrm{OH})_{3}$, alunite $\left(\mathrm{KAl}_{3}\left(\mathrm{SO}_{4}\right)(\mathrm{OH}) 6\right)$, bas- aluminite $\left(\mathrm{Al}_{4}(\mathrm{OH})_{10} \mathrm{SO}_{4}\right)$, boehmite $(\mathrm{AlOOH})$, diaspore $(\mathrm{AlOOH})$, ettringite, jurbanite $\left(\mathrm{AlOHSO}_{4}\right)$ and gibbsite $\left(\mathrm{Al}(\mathrm{OH})_{3}\right)$ could precipitate out when mine water was treated with FA (Fig. 12). Amorphous $\mathrm{Al}(\mathrm{OH})_{3}$, alunite, basaluminite and jurbanite are super- saturated between $\mathrm{pH} 4$ and 9, while 
boehmite, diaspore and gibbsite are supersaturated at $\mathrm{pH}$ greater than 4 . Ettringite is 1 supersaturated at $\mathrm{pH}$ greater than 10.

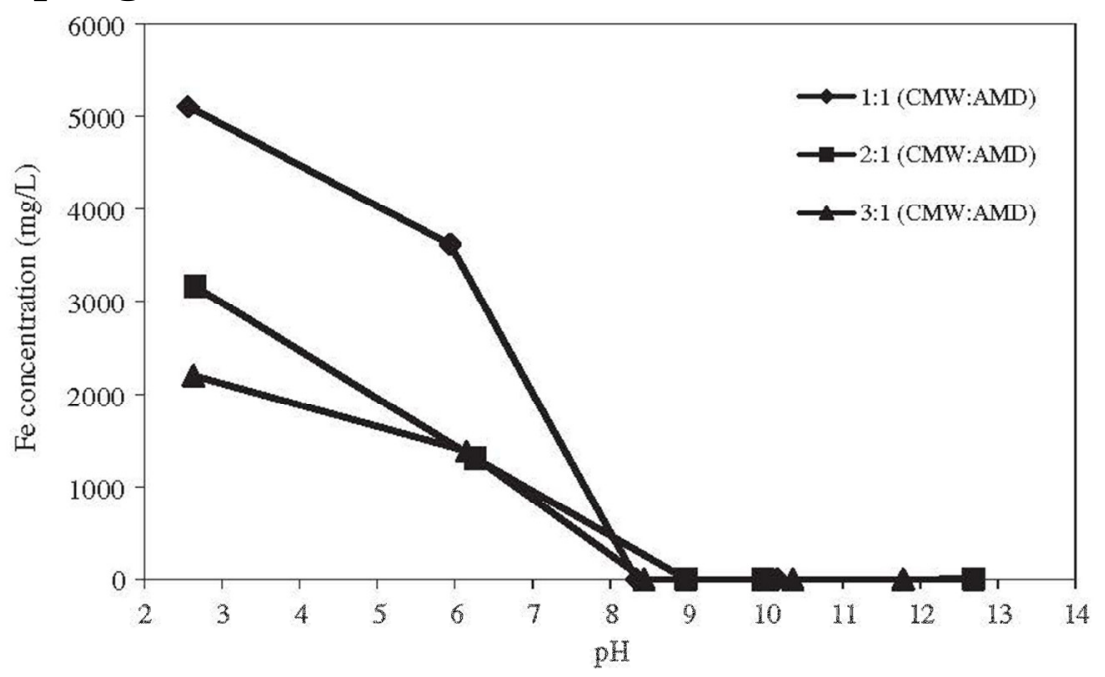

Fig. 13. Fe concentration during treatment of different CMWIAMD mixtures to various pH and points with FA.
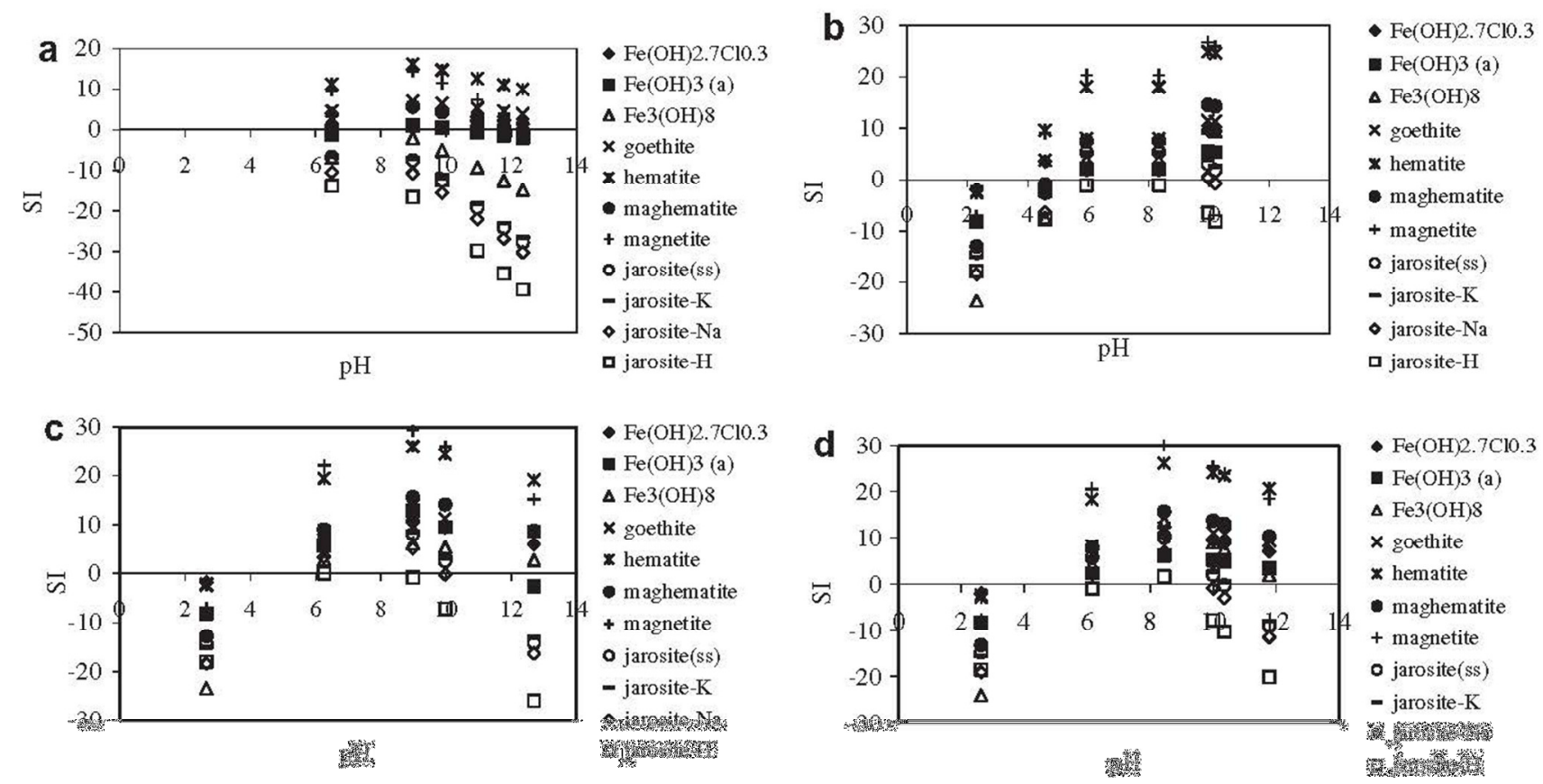

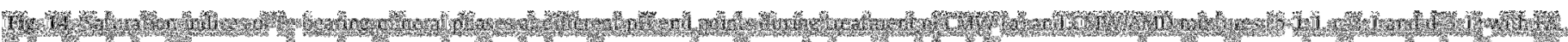

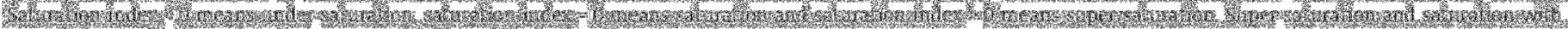

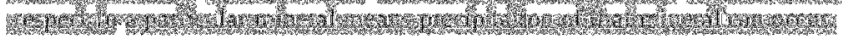

Treatment of 3:1, 2:1 and 1:1 CMW/AMD mixtures with FA have shown that the Fe concentration was reduced from between 2202 and $5108 \mathrm{mg} / \mathrm{L}$ to between 0.03 and $0.05 \mathrm{mg} / \mathrm{L}$ when $\mathrm{pH}$ was raised to 9. Iron starts precipitating from solution at $\mathrm{pH}$ greater than 5 when FA was mixed with the CMW/AMD mixtures (Fig. 13).

The SI indices were calculated for Fe-bearing mineral phases using PHREEQC model (Fig. 14). Calculated SI, show that Fe hydroxides, oxyhydroxides and oxyhydroxysulphate mineral phases started precipitating at $\mathrm{pH} 5$ (Fig. 14). The 
minerals controlling $\mathrm{Fe}$ removal according to the model are $\mathrm{Fe}(\mathrm{OH})_{2.7} \mathrm{ClO}_{0.3},{ }^{141}$ amorphous $\mathrm{Fe}(\mathrm{OH})_{3}, \mathrm{Fe}_{3}(\mathrm{OH}) 8$, goethite $(\mathrm{FeOOH})$, hematite $\left(\mathrm{Fe}_{2} \mathrm{O}_{3}\right)$, maghematite $\left(\mathrm{Fe}_{2} \mathrm{O}_{3}\right)$, magenetite $\left(\mathrm{Fe}_{3} \mathrm{O}_{4}\right)$, jarosite(ss) (Ko.77Nao.03 $\left.\mathrm{Ho.2}_{2}-\mathrm{Fe}_{3}\left(\mathrm{SO}_{4}\right)_{2}(\mathrm{OH})_{6}\right)$, jarosite- $\mathrm{K}\left(\mathrm{KFe}_{3}\left(\mathrm{SO}_{4}\right)_{2}(\mathrm{OH})_{6}\right.$, jarosite- $\mathrm{Na}\left(\mathrm{NaFe}_{3}-\left(\mathrm{SO}_{4}\right)_{2}(\mathrm{OH}) 6\right)$ and jarosite-H $\left(\mathrm{HFe}_{3}\left(\mathrm{SO}_{4}\right)_{2}(\mathrm{OH})_{6}\right)$. All other Fe bearing mineral phases are capable of precipitating at $\mathrm{pH}$ greater than 4 except jarosite- $\mathrm{H}$ which is stable at $\mathrm{pH} 6-7$, jarosite- $\mathrm{Na}$ is stable at $\mathrm{pH} 4-9$, while jarosite-K and jarosite(ss) are stable between $\mathrm{pH} 4$ and 10.

\subsection{General discussion}

This study has shown that sulphate, $\mathrm{Fe}, \mathrm{Al}, \mathrm{Mn}$ and $\mathrm{Mg}$ concen- trations in CMW and AMD can be reduced by manipulating their solution chemistry using South African coal fly ash. It has been re- vealed in this study that AMD can be used as a source of $\mathrm{Al}$ and $\mathrm{Fe}$ to facilitate sulphate removal from $\mathrm{CMW}$-fly ash system. A geo- chemical modelling tool (PHREEQC) can be used to explore the unique properties of CMW and AMD with a view to provide an understanding of appropriate treatment options for these waters. The PHREEQC software has been used successfully as a predictive tool to determine mineral phases and the forms in which sulphate; $\mathrm{Fe}, \mathrm{Al}$, $\mathrm{Mn}$ and $\mathrm{Mg}$ can be precipitated from mine water-fly ash systems. It has shown through modelling and experimentation that different precipitates are formed at different $\mathrm{pH}$ values and these precipitates are removed in different forms depending on the type of mine water.

South Africa is water scarce country. This water scarcity is exacerbated by the contamination of surface and groundwater with mine water. Treatment of mine water is very expensive and cheap ways are continually being sort. Coal FA is waste product and therefore treatment of mine water will go a long way in reducing the exorbitant costs associated with mine water treatment. Also use of coal FA in mine water treatment will be a step ahead in achieving zero effluent discharge in coal mines and coal fired power stations since both mine water and coal FA are environmental liabilities.

\section{Conclusion}

The results obtained in this study showed that treatment of mine water using FA is 
dependent on its elemental composition. These results are vital for miningy companies in coming up with a suitable treatment methods for the water they pump during their operations. Removal of sulphates, $\mathrm{Fe}, \mathrm{Al}, \mathrm{Mg}$ and $\mathrm{Mn}$ when $\mathrm{CMW}$ and AMD were treated with coal FA was found to be $\mathrm{pH}$ dependent. About $16 \%$ of sulphate were removed when CMW was treated with FA to $\mathrm{pH} 10$ and $71 \%$ of sulphate was removed when $\mathrm{pH}$ was in- creased beyond 10. In case of AMD blended with CMW $80 \%$ of sulphates were removed when the $\mathrm{pH}$ was raised to $10 \%$ and $90 \%$ was removed when $\mathrm{pH}$ of $\mathrm{AMD}$ was raised to greater 10. The enhanced removal of sulphate from $\mathrm{AMD} / \mathrm{CMW}$ mixture is due to the presence of $\mathrm{Fe}$ and $\mathrm{Al}$ that tend to buffer the rise in $\mathrm{pH}$ thereby increasing $\mathrm{CaO}$ dissolution hence more gypsum precipitation. In addition the presence of $\mathrm{Fe}$ and $\mathrm{Al}$ in $\mathrm{AMD}$ enhanced sulphate removal through precipitation of $\mathrm{Fe}$ and $\mathrm{Al}$ oxyhydroxysulphates. If the mine water $\mathrm{pH}$ was raised to greater than 6, 8, 9 and 11 it was found that approximately $100 \%$ of $\mathrm{Al}, \mathrm{Fe}, \mathrm{Mn}$ and $\mathrm{Mg}$ were removed respectively. The mineral phases that were responsible for sulphate removal were found to be alunite, anhydrite, barite, basaluminite, jurbanite, jarositess, jarosite- $\mathrm{K}$, jarosite-Na, jarosite- $\mathrm{H}$, celestite and gypsum. Iron was found to be precipitating in the form of $\mathrm{Fe}(\mathrm{OH})_{2.7} \mathrm{Clo}_{0.3}$, amorphous $\mathrm{Fe}(\mathrm{OH})_{3}, \mathrm{Fe}_{3}(\mathrm{OH})_{8}$, goethite, hematite, maghematite, magenetite, jarosite(ss), jarosite- $\mathrm{K}$, jarosite- $\mathrm{Na}$ and jarosite- $\mathrm{H}$, while $\mathrm{Al}$ was found to precipitate out as amorphous $\mathrm{Al}(\mathrm{OH})_{3}$, alunite, basaluminite, boehmite, diaspore, ettringite, jurbanite and gibbsite. Magnesium was found to be removed as brucite and Mn was found to remove as birnessite, bixbyite, hausamannite, manganite, nsutite, pyrochroite and pyrolusite. 


\section{References}

Adriano, D.C., Page, A.L., Elseewi, A.A., Chang, A.C., Straughan, I., 1980. Utilization and disposal of fly ash and other coal residues in terrestrial ecosystems: a review. Journal of Environment Quality 9, 333-344.

ASTM. Standard Specification for Fly Ash and Raw or Calcined Natural Pozzolan for use as Mineral Admixture in Portland Cement Concrete. American Society for Testing and Minerals, Pennsylvania.

Blowes, D.W., Ptacek, C.J., 1994. Acid-Neutralization Mechanisms in Active Mine Tailings-Handbook on Environmental Geochemistry of Sulfide Mine Waste, 22nd ed. Mineralogical Association of Canada, Nepean, pp. 271-291.

Bosman, D.J., 1983. Lime treatment of acid mine water and associated solids/liquid separation. Water Science and Technology 15, 71-84.

Conlon, W.J., 1990. Membrane Process. Water Quality and Treatment in A handbook of Community Water Supplies, 4th ed. American Water Works Association, McGraw-Hill Inc., pp. 561-640.

Davies, B.R., O'keeffe, J.H., Snaddon, C.D., 1993. A Synthesis of the Ecological Functioning, Conservation and Management of South African River Ecosystem. Water Research Commission, Pretoria.

Gitari, M.W., Petrik, L.F., Etchebers, O., Key, D.L., Iwuoha, E., Okujeni, C., 2006. Treatment of acid mine drainage with fly ash: removal of major contaminants and trace elements. Journal of Environmental Science and Health Part A-Toxic/ Hazardous Substances \& Environmental Engineering 41, 1729-1747.

Gitari, W.M., Petrik, L.F., Etchebers, O., Key, D.L., Iwuoha, E., Okujeni, C., 2008. Utilization of fly ash for treatment of coal mines waste water: solubility controls on major inorganic contaminants. Fuel 87, 2450-2462.

Hammack, R.W., de Vegt, A.L., Schoeneman, A.L., 2006. The removal of sulfates and metals from mine waters using bacterial sulfate reduction: pilot plant 
Hlabela, P., Maree, J., Bruinsma, D., 2007. Barium carbonate process for sulphate and metal removal from mine water. Mine Water and the Environment 26, 14-22. Jenke, R.D., Gordon, K.P., 1983. Chemical changes in concentrated, acidic, metal-bearing waste when treated with lime. Environmental Science and Technology 17 (4), 217-223.

Johnson, D.B., Hallberg, K.B., 2005. Acid mine drainage remediation options: a review. Science of the Total Environment 3389 (2), 3-14.

Lottermoser, B.G., 2007. Mine Wastes: Characterization, Treatment and Environmental Impacts, 2nd ed. Springer.

Madzivire, G., 2010. Removal of sulphates from South African mine water using coal fly ash, M.Sc. Thesis, University of the Western Cape, Cape Town South Africa.

Madzivire, G., Petrik, L.F., Gitari, W.M., Ojumu, T.V., Balfour, G., 2010. Application of coal fly ash to circumneutral mine waters for the removal of sulphates as gypsum and ettringite. Mineral Engineering 23, 252-257.

Maree, J.P., Bosman, D.J., Jenkins, G.R., 1989. Chemical removal of sulphates, calcium and heavy metals from mining and power station effluents. Water Sewage and Effluents 9, 10-25.

Mattigod, S.V., Rai, Dhanpat, Eary, L.E., Ainsworth, C.C., 1990. Geochemical factors controlling the mobilization of inorganic constituents from fossil fuel combustion residues: review of the major elements. Journal of Environment Quality 9, 188-201.

Parkhurst, D.L., Appelo, C.A.J., 1999. User Guide to PHREEQC (Version 2)-A Computer Program for Speciation, Batch-Reaction, One Dimensional Transport, and Inverse Geochemical Calculations, USGS.

Perkins, R.B., Palmer, C.D., 1999. Solubility of ettringite $\left(\mathrm{Ca} 6[\mathrm{Al}(\mathrm{OH}) 6]_{2}\left(\mathrm{SO}_{4}\right)_{3}-26 \mathrm{H}_{2} \mathrm{O}\right)$ at $5-75{ }^{\circ} \mathrm{C}$. Geochimica et Cosmochimica Acta 63 (13), 1969-1980.

Petrik, L.F., White, R.A., Klink, M.J., Somerset, V.S., Burgers, C.L., Fey, M.V., 2003. Utilization of South African fly ash to treat acid coal mine drainage, and production of high quality zeolites from the residual solids. In: Proc. International Ash Utilization Symposium. University of Kentucky, Centre of Applied Energy Research, pp. 1-26. 
Uhlmann, W., Buttcher, H., Totsche, O., Steinberg, C.E.W., 2004. Buffering 'off acidic mine lakes: the relevance of surface exchange and solid bound sulphate. Mine Water and Environment 23, 20-27.

Vadapalli, V.R.K., Klink, M.J., Etchebers, O., Petrik, L.F., Gitari, W., White, R.A., Key, D., Iwuoha, E., 2008. Neutralization of acid mine drainage using fly ash, and strength development of the solid residues. South African Journal of Science 104, 317-322.

Younger, P.L., Banwart, S.A., Hedin, R.S., 2002. Mine Water: Hydrology. Dordrecht Kluwer Academic Publishers. 